Acta Agroph., 2020, 27, 31-38

doi: $10.31545 /$ aagr/126566

Note

\title{
FEEDING VALUE OF DE-HULLED SUNFLOWER SEED MEAL FOR BROILERS*
}

\author{
Nikolay Karkelanov ${ }^{1,2}$, Sashka Chobanova ${ }^{2}$, \\ Katya Dimitrova ${ }^{1}$, Isobel M. Whiting ${ }^{1}$, Stephen P. Rose ${ }^{1} \mathbb{B}_{2}$ Vasil Pirgozliev $^{1} \mathbb{D}$ \\ ${ }^{1}$ The National Institute of Poultry Husbandry, Harper Adams University, Newport, Shrops, England, \\ United Kingdom \\ ${ }^{2}$ Faculty of Agriculture, Trakia University, Bulgaria \\ e-mail: vpirgozliev@harper-adams.ac.uk
}

\begin{abstract}
The effects of de-hulled sunflower seed meal (SFM) samples with different crude protein (CP) and non-starch polysaccharide (NSP) content on apparent metabolizable energy (AME), AME metabolizability (EM) and pre-caecal protein digestibility (pcPD) were examined. The birds were fed one of four mash diets. On a per kilogram basis, the basal diet (BD) contained as major ingredients $549.5 \mathrm{~g}$ wheat, $150 \mathrm{~g}$ soybean meal and $175 \mathrm{~g}$ full fat soybean meal as well as $215.4 \mathrm{~g}$ crude protein $\mathrm{kg}^{-1}$ and $12.81 \mathrm{MJ}$ AME kg${ }^{-1}$. Another three diets containing $200 \mathrm{~g} \mathrm{~kg}^{-1}$ of each of three experimental SFM samples in place of the BD were also mixed. Each diet was fed to birds in ten pens with two male Ross 308 broilers ranging in age from 8 to 21 days. Dietary AME was determined from excreta collection between days 17 and 21, while AME, EM and pcPD were determined when the birds were 21 days old. The substitutional method was used to determine AME, EM and pcPD in the SFM samples. The SFM samples high in NSP had lower AME $(\mathrm{P}=0.001), \mathrm{EM}(\mathrm{P}<0.001)$ and pcPD $(\mathrm{P}=0.005)$. The beneficial effect of carrying out a further de-hulling of SFM seems to be mediated through reduced NSP content and improved energy and protein bioavailability.
\end{abstract}

Keyw ords: sunflower seed meal, broiler chickens, protein digestibility, metabolizable energy

\section{INTRODUCTION}

The EU poultry industry relies heavily on imported soybean meal (SBM) as a protein source in feed. Over recent years, the demand for sustainable feed ingredients has risen, thereby increasing the need to develop alternative protein sources for modern poultry production (Abdulla et al. 2016; Whiting et al. 2017, Watts et al., 2019). Sunflower meal (SFM) has the potential to be a major feed ingredient for poultry in many countries not suitable for extensive soybean cultivation (Sredanović et al. 2014, Waititu et al. 2018). Compared with SBM, SFM has relatively low lysine

* The project was supported by the ERASMUS Plus programme and The National Institute of Poultry Husbandry, Harper Adams University, UK. 
and methionine and significant higher fibre contents. Moreover, the de-hulling process of SFM has been further improved to allow the production of high-protein SFM which may contain over $40 \%$ crude protein $(\mathrm{CP})$ and less than $10 \%$ fibre (Waititu et al. 2018). It has been shown that SFM may be used as a substitute for SBM in poultry diets which are balanced in metabolizable energy, total crude protein, lysine, methionine, threonine and tryptophan, and the major minerals (Sredanović et al. 2014). The aim of the study was to compare the content of apparent metabolizable energy (AME), AME metabolizability (EM) expressed as a ratio between AME and gross energy (GE) and the pre-caecal crude protein digestibility (pcPD) of three SFM samples obtained from three different manufacturers. The growth performance of the birds was also determined to attempt to establish if there are differences in growth performance that might affect the estimates of nutrient availability.

\section{MATERIALS AND METHODS}

\section{Experimental samples}

This study is focused on the nutritional value for broilers of three de-hulled sunflower meal (SFM) samples produced by different manufacturers. The three SFM samples used in the study were produced during the 2018 harvest year. SFM \# 1 was produced by Maritza Oil AD (Pazardzhik, Bulgaria). In brief, the seeds were initially de-hulled as only about $50 \%$ of the hulls remained thereby assuring better conditions for oil separation. The material was then milled in a roller mill, conditioned at $3 \%$ humidity and $114^{\circ} \mathrm{C}$, and the product of this process was then moved to a press at $105-114^{\circ} \mathrm{C}$ and about $3-3.5 \%$ humidity. The product of this preliminary phase contains about $10 \%$ fat, which is then hexane extracted and the obtained SFM usually contains about $37 \%$ CP and less than $1 \%$ fat. SFM \# 2 was produced by Biser Oliva AD (Stara Zagora, Bulgaria) following similar technological processes as for SFM \# 1, but with the application of slightly better de-hulling techniques and containing about $40 \% \mathrm{CP}$ and less fibres, compared to SFM \# 1 . SFM \# 3 was produced by Tivatrade LTD (Sofia, Bulgaria). The de-hulling process continued further with already roughly de-hulled SFM producing a meal with a CP value ranging between 43 to $45 \%$ and a very low fibre content. All of the experimental SFM samples were stored at ambient air temperatures in a dry store. The SFM samples were not subjected to any freezing temperatures during this period.

\section{Laboratory analysis of the samples}

Proximate analysis of the feed and excreta samples were performed as explained by Hejdysz et al. (2018). The NSP content in the SFM samples was determined using the method of Englyst et al. (1994), whereby starch is completely dispersed and then hydrolysed enzymatically. 


\section{Diet preparation}

The birds were fed one of four mash diets. A Control diet was prepared which on a per kilogram basis had the major ingredients of $549.5 \mathrm{~g}$ wheat, $150 \mathrm{~g}$ high protein soybean meal (SBM) and $175 \mathrm{~g}$ full fat SBM, and contained $215 \mathrm{~g} \mathrm{~kg}^{-1} \mathrm{CP}$ and $12.81 \mathrm{MJ} \mathrm{kg}^{-1} \mathrm{AME}$, which was in agreement with the recommendations of the breeder (Aviagen Ltd., Edinburgh, UK), (Table 1). Acid insoluble ash (AIA) was used as an indigestible marker. Another three diets containing $200 \mathrm{~g} \mathrm{~kg}^{-1}$ for each of the three experimental SFM samples as a replacement for the Control diet were also mixed. In order to achieve improved homogenization, the diets containing SFM were thoroughly mixed in a horizontal mixer for six minutes. The diets were free from coccidiostat, antimicrobial growth promoters, prophylactic and other similar additives.

Table 1. Ingredient composition ( $\mathrm{g} \mathrm{kg}^{-1}$ 'as fed') and calculated analysis of the basal diets

\begin{tabular}{|c|c|}
\hline Ingredient & $\left(\mathrm{g} \mathrm{kg}^{-1}\right)$ \\
\hline Wheat & 549.50 \\
\hline Maize gluten meal & 10.00 \\
\hline Soybean meal & 150.00 \\
\hline Full fat soybean meal & 175.00 \\
\hline Monocalcium phosphate & 20.00 \\
\hline Limestone & 15.00 \\
\hline $\mathrm{NaCl}$ & 3.80 \\
\hline Soya oil & 40.00 \\
\hline Lysine HCL & 4.00 \\
\hline Methionine & 4.00 \\
\hline Threonine & 1.90 \\
\hline Vitamin premix & 6.30 \\
\hline Acid insoluble ash & $\begin{array}{l}20.00 \\
1000\end{array}$ \\
\hline \multicolumn{2}{|l|}{ Calculated analyses } \\
\hline $\begin{array}{l}\text { ME }\left(\mathrm{MJ} \mathrm{kg}^{-1}\right) \\
\text { Crude protein }\left(\mathrm{g} \mathrm{kg}^{-1}\right)\end{array}$ & $\begin{array}{l}12.81 \\
215.4\end{array}$ \\
\hline Crude fat $\left(\mathrm{g} \mathrm{kg}^{-1}\right)$ & 80.90 \\
\hline $\mathrm{Ca}\left(\mathrm{g} \mathrm{kg}^{-1}\right)$ & 11.20 \\
\hline Available P $\left(\mathrm{g} \mathrm{kg}^{-1}\right)$ & 5.80 \\
\hline Lysine $\left(\mathrm{g} \mathrm{kg}^{-1}\right)$ & 14.70 \\
\hline Met + cyst $\left(\mathrm{g} \mathrm{kg}^{-1}\right)$ & 9.70 \\
\hline $\mathrm{DM}\left(\mathrm{g} \mathrm{kg}^{-1}\right)$ & 901 \\
\hline $\mathrm{GE}\left(\mathrm{MJ} \mathrm{kg}^{-1}\right)$ & 17.81 \\
\hline Crude protein $\left(\mathrm{g} \mathrm{kg}^{-1}\right)$ & 210.90 \\
\hline Crude fat $\left(\mathrm{g} \mathrm{kg}^{-1}\right)$ & 71.00 \\
\hline Total non-starch polysaccharide & 97.00 \\
\hline Soluble non-starch polysaccharides $\left(\mathrm{g} \mathrm{kg}^{-1}\right)$ & 32.00 \\
\hline Insoluble non-starch polysaccharides $(\mathrm{g} \mathrm{kg}$ & 65.00 \\
\hline
\end{tabular}

This balancer was also fed as a part of a complete diet which comprised $200 \mathrm{~g} \mathrm{~kg}^{-1}$ from each experimental sunflower meal sample and $800 \mathrm{~g} \mathrm{~kg}^{-1}$ of the balancer. Each experimental diet met the diet specification for this strain of broiler chicken (Aviagen Ltd., Edinburgh, UK). The vitamin and mineral premix contained vitamins and trace elements to meet the breeder's recommendations (Aviagen Ltd., Edinburgh, $\mathrm{UK}$ ). The vitamin and mineral premix provided per $\mathrm{kg}$ of diet: $50 \mathrm{mg}$ nicotinic acid, $34 \mathrm{mg} \alpha$-tocopherol, $15 \mathrm{mg}$ pantothenic acid, $7 \mathrm{mg}$ riboflavin, $5 \mathrm{mg}$ pyridoxine, $3.6 \mathrm{mg}$ retinol, $3 \mathrm{mg}$ menadione, $2 \mathrm{mg}$ thiamine, $1 \mathrm{mg}$ folic acid, $200 \mu \mathrm{g}$ biotin, $125 \mu \mathrm{g}$ cholecalciferol, $15 \mu \mathrm{g}$ cobalamin, $100 \mathrm{mg}$ manganese, $80 \mathrm{mg}$ iron, $80 \mathrm{mg}$ zinc, $10 \mathrm{mg}$ copper, $1 \mathrm{mg}$ iodine, $0.5 \mathrm{mg}$ cobalt, $0.5 \mathrm{mg}$ molybdenum and $0.2 \mathrm{mg}$ selenium. 


\section{Animals, sampling and estimation of performance data}

The experiment was conducted at the National Institute of Poultry Husbandry and approved by the Research Ethics Committee of Harper Adams University, UK. Male Ross 308 broiler chickens were obtained from a commercial hatchery. During the pre-study period, from day old to 7 days old, the birds were reared in a single floor pen and fed the Control diet. At the beginning of the study, at 8 days of age, 80 chicks were allocated to 40 small pens with a $0.160 \mathrm{~m}^{2}$ solid floor area, with 2 birds in each pen. The room temperature and lighting programme followed the breeder's recommendations (Aviagen Ltd., Edinburgh, UK). The feed and water was offered ad libitum to the birds throughout the experiment. Each diet was offered to the birds in ten pens in a randomized block design. Information concerning their growth performances was obtained from 8 days to 21 days of age. Excreta were collected quantitatively for the last 4 days of the study from birds of 17 to 21 days of age. At the end of the study, when the birds were 21 days old, the two birds in each pen were electrically stunned and digesta from the ileum were collected, pooled on a per pen basis, freeze dried, milled and subjected to further analysis. The AIA content in diets, excreta and digesta was measured as described by Van Keulen and Young (1977). Dietary AME, EM and pcPD were determined as explained by Chibowska et al. (2000).

\section{Statistical analysis}

The growth performance variables including feed intake, weight gain and the feed conversion ratio were only compared between birds fed on SFM containing diets. The energy metabolism and pre-caecal protein digestibility values of the SFM samples were obtained using the substitutional method. All data were analysed using analysis of variance (ANOVA) in GenStat ${ }^{\circledR}\left(19^{\text {th }}\right.$ edition, Rothamstead, Hertfordshire, UK), differences were reported as significant at $\mathrm{P}<0.05$. Post hoc Tukey's range test was used to differentiate between the treatment means.

\section{RESULTS}

SFM proximate compositions are summarized in Table 2 . The samples contained relatively low amounts of fat. The SFM sample with the lowest fat content, SFM \# 2, and the sample with higher fat content, SFM \# 1, had the highest and the lowest dry matter contents, respectively. The amount of $\mathrm{CP}$ was more variable than the gross energy content and ranged from 374 to $425 \mathrm{~g} \mathrm{~kg}^{-1}$, respectively.

Table 2. Chemical composition of the experimental sunflower meal (SFM) samples

\begin{tabular}{|c|c|c|c|c|}
\hline SFM & Dry matter $\left(\mathrm{g} \mathrm{kg}^{-1}\right)$ & Crude protein $\left(\mathrm{g} \mathrm{kg}^{-1}\right)$ & Crude fat $\left(\mathrm{g} \mathrm{kg}^{-1}\right)$ & Gross energy $\left(\mathrm{MJ} \mathrm{kg}^{-1}\right)$ \\
\hline$\# 1$ & 914 & 374 & 4.2 & 17.70 \\
\hline$\# 2$ & 953 & 400 & 1.0 & 17.94 \\
\hline \# 3 & 931 & 425 & 4.1 & 17.44 \\
\hline $\mathrm{SD}$ & 19.55 & 25.50 & 1.82 & 0.25 \\
\hline
\end{tabular}

All data are the results of a chemical analysis conducted in triplicate; SD: standard deviation. 
The mean total NSP content of the SFM samples was $197 \mathrm{~g} \mathrm{~kg}^{-1}$, comprising $50 \mathrm{~g} \mathrm{~kg}^{-1}$ of soluble and $147 \mathrm{~g} \mathrm{~kg}^{-1}$ of insoluble NSP, respectively (Table 3). Glucose and xylose were the main NSP constituent sugars in the SFM samples. SFM \# 3 had not only the lowest NSP content but also low xylose and glucose levels compared to the rest.

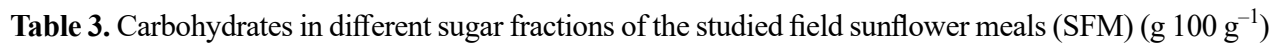

\begin{tabular}{llcccccccccc}
\hline SFM & \multicolumn{1}{c}{ Carbohydrates } & rha & fuc & ara & xyl & man & gal & glu & GlcA & GalA & $\begin{array}{r}\text { Total NSP } \\
\left(\mathrm{g} 100 ~ g^{-1}\right)\end{array}$ \\
\hline$\# 1$ & Soluble sugars & 0.2 & 0.0 & 1.0 & 0.5 & 0.0 & 0.6 & 0.9 & 0.1 & 1.7 & 5.1 \\
& Insoluble sugars & 0.2 & 0.1 & 2.1 & 3.3 & 1.3 & 0.6 & 8.2 & 0.0 & 1.0 & 16.6 \\
\multirow{2}{*}{ Total sugars } & 0.3 & 0.1 & 3.1 & 3.8 & 1.3 & 1.2 & 9.1 & 0.1 & 2.7 & 21.7 \\
& Soluble sugars & 0.1 & 0.0 & 1.3 & 0.3 & 0.0 & 0.5 & 0.8 & 0.0 & 1.7 & 4.8 \\
& Insoluble sugars & 0.2 & 0.1 & 1.9 & 3.1 & 1.0 & 0.6 & 7.7 & 0.0 & 0.8 & 15.4 \\
& Total sugars & 0.3 & 0.1 & 3.2 & 3.4 & 1.1 & 1.1 & 8.5 & 0.0 & 2.5 & 20.2 \\
$\# 3$ & Soluble sugars & 0.2 & 0.1 & 1.3 & 0.3 & 0.1 & 0.6 & 0.3 & 0.1 & 2.3 & 5.2 \\
& Insoluble sugars & 0.1 & 0.1 & 1.9 & 1.6 & 1.1 & 0.6 & 5.7 & 0.0 & 0.9 & 12.0 \\
& Total sugars & 0.3 & 0.1 & 3.2 & 1.9 & 1.1 & 1.3 & 5.9 & 0.1 & 3.2 & 17.2 \\
& SD Soluble sugars & 0.06 & 0.06 & 0.17 & 0.12 & 0.06 & 0.06 & 0.32 & 0.06 & 0.35 & 0.21 \\
& SD Insoluble sugars & 0.06 & 0.00 & 0.12 & 0.93 & 0.15 & 0.00 & 1.32 & 0.00 & 0.10 & 2.39 \\
& SD Total sugars & 0.00 & 0.00 & 0.06 & 1.00 & 0.12 & 0.10 & 1.70 & 0.06 & 0.36 & 2.29 \\
\hline
\end{tabular}

All data are the result of a chemical analysis conducted in duplicate; NSP: non-starch polysaccharides; rha:rhamnose; fuc:fucose; ara: arabinose; xyl: xylose; man: mannose; gal: galactose, glu: glucose; GlcA:glucuronic acid; GalA: galacturonic acid; SD: standard deviation.

There were no mortalities recorded as all of the birds survived the experiment. The data concerning the growth performance, energy and nutrient availability of the SFM samples is presented in Table 4.

Table 4. The impact of the experimental sunflower meal (SFM) samples on feed intake (FI), weight gain (WG), feed conversion ratio (FCR), apparent metabolizable energy (AME), energy metabolizability (EM) and pre-caecal protein digestibility (pcPD) when fed to broiler chickens

\begin{tabular}{lcccccc}
\hline \multicolumn{1}{c}{ SFM } & $\begin{array}{c}\mathrm{FI} \\
\left(\mathrm{kg} \mathrm{bird}^{-1}\right)\end{array}$ & $\begin{array}{c}\text { WG } \\
\left(\mathrm{kg} \mathrm{bird}^{-1}\right)\end{array}$ & $\begin{array}{c}\text { FCR } \\
\left(\mathrm{kg} \mathrm{kg}^{-1}\right)\end{array}$ & $\begin{array}{c}\text { AME } \\
\left(\mathrm{MJ} \mathrm{kg}^{-1} \mathrm{DM}\right)\end{array}$ & EM & pcPD \\
\hline 1 & 0.751 & 0.490 & 1.539 & $6.17^{\mathrm{a}}$ & $0.319^{\mathrm{a}}$ & $0.516^{\mathrm{a}}$ \\
2 & 0.729 & 0.465 & 1.583 & $7.04^{\mathrm{ab}}$ & $0.374^{\mathrm{ab}}$ & $0.587^{\mathrm{ab}}$ \\
3 & 0.724 & 0.491 & 1.486 & $8.04^{\mathrm{b}}$ & $0.429^{\mathrm{b}}$ & $0.697^{\mathrm{b}}$ \\
SEM (df = 29) & 0.0154 & 0.0198 & 0.0418 & 0.291 & 0.0155 & 0.0228 \\
cV \% & 6.6 & 13.0 & 8.6 & 13.0 & 13.1 & 17.8 \\
$\mathrm{P}$ & 0.418 & 0.587 & 0.285 & 0.001 & $<0.001$ & 0.005 \\
\hline
\end{tabular}

$\mathrm{SEM}=$ pooled standard errors of mean; $\mathrm{df}=$ residual degree of freedom; $\mathrm{cv} \%=$ coefficient of variation; P = Fisher probability; FI, WG and FCR were determined for feeding diets containing $200 \mathrm{~g} / \mathrm{kg}$ SFM for 14 days for birds between 8 and 21 days of age; AME was determined on excreta collected for the last four days of the study; pcPD was determined on digesta obtained from 21day old birds; both, AME and pcPD were obtained using the substitutional method. ${ }^{\mathrm{a}, \mathrm{b}}$ Within the AME, EM and pcPD values in a column, those not sharing a common superscript are significantly different. 
There were no differences in FI, WG and FCR among the birds fed with the three SFM samples $(\mathrm{P}>0.05)$. SFM \# 3 was characterized by an improved AME $(\mathrm{P}=0.001), \mathrm{EM}(\mathrm{P}<0.001)$ and pcPD coefficient $(\mathrm{P}=0.005)$ compared to SFM \# 3, although SFM \# 2 did not differ from the rest.

\section{DISCUSSION}

Studying the feeding values of differently processed SFM for poultry is important because sunflower is cultivated in EU countries and can be used as a home grown alternative protein source in poultry diets. The chemical composition of the SFM samples evaluated in the current study were similar to those previously reported (Sredanović et al. 2014, Pereira and Adeola 2016, Waititu et al. 2018). The variation in CP, EE and NSP contents between the SFM samples was expected because of the use of different manufactures. The use of recent technological advances in de-hulling used in the production of SFM \# 3 led to a CP value of $43 \%$ and a total NSP of $17 \%$, which was superior to the other two SFM samples. SFM \# 2 also had 7\% more CP and 7\% less NSP compared to SFM \# 1. Consequently, the reduction in NSP led to improved energy and protein availability in SFM.

Thus, AME, EM and pcPD in SFM samples decreased with increasing fibre levels indicating that the hulls had a negative effect on energy and protein bioavailability (Hetland et al. 2004). This result occurred along with the numerically lower growth performance of the same birds. In addition, the degradation of the NSP constituents is far lower in chickens than in other animal species such as pigs and rats, thus supporting the view that chickens do not ferment fibre polymers to a great extent (Jørgensen et al. 1996). Moreover, diets with high NSP levels promote a greater degree of bacterial translocation from the gut to the blood system, due to the development of a leaky gut that can produce systemic infection and a low-grade inflammatory response in the intestine of broilers (Cardoso Dal Pont et al. 2020). Thus, the suggestion that the further development of de-hulling technology and the consequent reduction in NSP content in SFM may be a way of improving its feeding value for poultry. Dietary supplementation with NSP degrading enzymes, such as xylanase, may further alleviate the negative impact of NSP in SFM.

\section{CONCLUSIONS}

The results showed that the feeding value of different SFM samples produced by different production plants may vary when fed to broiler chickens. The differences in NSP content between the samples indicates the need to consider an improvement in the de-hulling process in SFM production. When formulating poultry diets containing SFM, information concerning energy and nutrient contents and availability 
is important to ensure that diets are balanced. In general, the findings from this study indicate the bioavailability of energy and crude protein within the range of published data with broilers, and variance between producers.

\section{ACKNOWLEDGEMENT}

We thank Richard James and Rose Crocker for their technical support.

Conflict of interest: No potential conflict of interest was reported by the authors.

\section{REFERENCES}

Abdulla J., Rose S.P., Mackenzie A.M., Mirza W., Pirgozliev V., 2016. Exogenous tannase improves feeding value of a diet containing field beans (Vicia faba) when fed to broilers. Brit. Poult. Sci., 57(2), 246-250, https://doi.org/10.1080/00071668.2016.1143551

Cardoso Dal Pont G., Farnell M., Farnell Y., Kogut M.H., 2020. Dietary factors as triggers of lowgrade chronic intestinal inflammation in poultry. Microorganisms, 8(1), 139, https://doi.org/ 10.3390/microorganisms8010139

Chibowska M., Smulikowska S., Pastuszewska B., 2000. Metabolisable energy value of rapeseed meal and its fractions for chickens as affected by oil and fibre content. J. Anim. Feed Sci., 9(2), 371-378, https://doi.org/10.22358/jafs/68054/2000

Englyst H.N., Quigley M.E., Hudson G.J., 1994. Determination of dietary fibre as non-starch polysaccharides with gas-liquid chromatographic, high-performance liquid chromatographic or spectrophotometric measurement of constituent sugars. Analyst, 119(7), 1497-1509, https://doi.org/ 10.1039/AN9941901497

Hetland H., Choct M., Svihus B., 2004. Role of insoluble non-starch polysaccharides in poultry nutrition. World's Poult. Sci. J., 60(4), 415-422, https://doi.org/10.1079/WPS200325

Hejdysz M., Kaczmarek S.A., Kubiś M., Jamroz D., Kasprowicz-Potocka M., Zaworska A., Rutkowski A., 2018. Effect of increasing levels of raw and extruded narrow-leafed lupin seeds in broiler diet on performance parameters, nutrient digestibility and AME N value of diet. J. Anim. Feed Sci., 27, 55-64, https://doi.org/10.22358/jafs/83015/2018

Jørgensen H., Zhao X.Q., Knudsen K.E., Eggum B.O., 1996. The influence of dietary fibre source and level on the development of the gastrointestinal tract, digestibility and energy metabolism in broiler chickens. Brit. J. Nutr., 75(3), 379-395, https://doi.org/10.1079/BJN19960141

Pereira L.F.P., Adeola O., 2016. Energy and phosphorus values of sunflower meal and rice bran for broiler chickens using the regression method. Poult. Sci., 95(9), 2081-2089, https://doi. org $/ 10.3382 /$ ps/pew089

Sredanović, S.A., Lević, J.D., Jovanović, R.D. and Đuragić, O.M., 2012. The nutritive value of poultry diets containing sunflower meal supplemented by enzymes. Acta Period. Tech. 43, 79-91, https://doi.org/10.2298/APT1243079S

Van Keulen J.Y.B.A., Young B.A., 1977. Evaluation of acid-insoluble ash as a natural marker in ruminant digestibility studies. J. Anim. Sci., 44, 282-287, https://doi.org/10.2527/jas1977.442282x 
Whiting I.M., Pirgozliev V., Rose S.P., Wilson J., Amerah A.M., Ivanova S.G., Staykova G.P., Oluwatosin O.O., Oso A.O., 2017. Nutrient availability of different batches of wheat distillers dried grains with solubles with and without exogenous enzymes for broiler chickens. Poult. Sci., 96(3), 574-580, https://doi.org/10.3382/ps/pew262

Waititu S.M., Sanjayan N., Hossain M.M., Leterme P., Nyachoti C.M., 2018. Improvement of the nutritional value of high-protein sunflower meal for broiler chickens using multi-enzyme mixtures. Poult. Sci., 97, 1245-1252, https://doi.org/10.3382/ps/pex418

Watts E.S., Rose S.P., Mackenzie A.M., Pirgozliev V.R., 2020. The effects of supercritical carbon dioxide extraction and cold-pressed hexane extraction on the chemical composition and feeding value of rapeseed meal for broiler chickens. Arch. Anim. Nutr., 74(1), 57-71, https://doi.org/10.1080/ 1745039X.2019.1659702 